\title{
Shadow Puppet Transmedia as Created by Subandi Giyanto: An Ethnographic Study Perspective
}

\author{
Ratika Dwi Anggraini1, ${ }^{1, *}$ Martono ${ }^{2, * *}$ \\ ${ }^{1}$ Arts Education Graduate Program, Yogyakarta State University, Depok 55281, Yogyakarta, Indonesia \\ ${ }^{2}$ Department of Fine Arts Education, Yogyakarta State University, Depok 55281, Yogyakarta, Indonesia \\ *Corresponding author. Email: ratikaanggraini@gmail.com \\ ${ }^{* *}$ Corresponding author.Email: martonouny@gmail.com
}

\begin{abstract}
Subandi Giyanto is an artist pursuing his interest in puppetry since his very young age. His works have continued to morph through various forms and the media used have been also diverse because Giyanto has been motivated in exploiting and experimenting with his creation. Starting from Yogyakarta's leather puppets to decorative canvas painting, he innovatively responds to development of the arts. This study focuses on the artist's creative process and the preservation of leather puppets he does. The method used is qualitatively descriptive with Spradley's ethnographic approach. Data were gathered from informants as the initial key to data exploration through observation, interview, and documentation. Then, they were analyzed by using Spradley's ethnographic approach to describe the structural history of the various forms of Giyanto's works from then on. This research revels (1) the influence of Giyanto's educational and social background in each of his works, (2) the metaphorical creative process employed from the beginning of his career to the present, and (3) the development of the artist's work in industry 4.0.
\end{abstract}

Keywords: Subandi Giyanto, Wayang, Transmedia

\section{INTRODUCTION}

Yogyakarta is one of two regions in Indonesia with a Special Region status. It is also known as the city of culture, an inevitable title due to its association with the Ngayogyakarta Hadiningrat Sultanate Palace, the centre of culture and civilization for Javanese people, which retains its authority and plays a significant role in the development of culture, particularly in Yogyakarta. Performance art shows and traditional ceremonies are very much alive in the city, including shadow puppet (wayang), karawitan, labuhan, sekaten, and many others.

According to Ardian Kresna, shadow puppet is an attempt of the Javanese ancestors to depict a manifestation of the human life in general. They believe that every object has a spirit, a good one and a bad one. Around 1500 BC, shadow puppets were created to depict an illusion or shadow [1]. The shadow puppet procession which includes offerings becomes a part of a religious ceremony (animism). Once the teachings of Hindu, Buddhism, and Islam become popular in Java, the role and functions of shadow puppet transform into a means of promoting religious teachings. As a result, several characters' names were adjusted based on the religion.

Nowadays, shadow puppet is an invaluable form of art and culture, both as a cultural resource or a cultural product, that still survives in the midst of the increasingly globalized Indonesian people. The distribution of leather shadow puppet in Indonesia begins in the Java Island and its surroundings as it is perceived as a form of expression of the values of the community that form the nation's cultural character of the local community. As a cultural resource, the philosophical meanings contained in shadow puppet is directly related to various aspects of human life, while as a cultural product, it is indeed a manifestation of the creative process and innovation which directly or indirectly plays a role in the improvement of the social welfare of the community. The art of making shadow puppet is also known as tatah sungging.

Tatah means "sculpting" or making a certain pattern or shape by puncturing a piece of material, while sungging, according to Mikke Susanto, means "drawing." In Javanese culture, this term is associated with drawing book illustrations. A juru sungging or illustrator typically works on the drawings or illustration on the Palace manuscripts in the past which tells stories from the shadow puppet plays such as Ramayana or Mahabharata [2]. The modern meaning of sungging refers to the dyeing technique on shadow puppets which has a distinct feature of colour gradation. Marsudi points out that the Indonesian people consider tatah sungging as a noble and great craftmanship that is commonly found in the centres of government during the great kingdom era in the Indonesian archipelago [3]. The art of tatah sungging is a leather craft work which uses the parchment made of the cattle leather as the main material. The leather is then sculpted and painted into a shadow puppet. Tatah sungging has become the main occupation of many people to earn a living. This suggests 
that the knowledge and skills of this craft are maintained in the community. For the community, tatah sungging has various values, including the economic value, moral or educational value, art value, cultural value, as well as historical and cultural preservation value. These values are embedded in the life of the people of Yogyakarta since a long time ago.

In the art of painting, shadow puppet often serves as the source of inspiration for creating new works of art which focuses on culture, or for depicting the shadow puppet character in a piece of art. There are a great number of painters in Indonesia who take inspiration from shadow puppet as their muse or inspiration for their art creation. One of them is an artist native to Bantul named Subandi Giyanto, which is in fact more widely known as a shadow puppet artist.

It is particularly interesting to conduct an in-depth study the transmedia evolvement of Subandi Giyanto in creating his works. In addition to Subandi's dedication as an artist which uniquely take the classical element that is shadow puppet into his works, part of what makes him interesting to study is his creative explorative process in producing arts. With every work he makes, Subandi continues to evolve to find his identity. Because of this, many university students conduct a study on Subandi's process and works for their final thesis or assignments. The research papers are uploaded online and available for public access. In addition, Subandi regularly uploads his latest works on his personal Instagram account, allowing a wider audience to connect more to his art. Therefore, Subandi's works exist not only in his actual pieces of artworks, but also in the virtual world in the form of the student works and the photos he posts.

This is a qualitative descriptive study using an ethnographic approach, with the following objectives: (1) to describe the influence of the artist's background in his works; (2) to describe the transmedia creative process of the artist from the beginning of his career to the present time; and (3) to describe the influence of the artist's career development in the 4.0 industry era.

\section{RESEARCH METHOD}

The method used in this research is the descriptive qualitative method with an ethnographic study approach. Sugiyono argues that in general the research method is defined as a scientific way to obtain data with specific purposes and uses. There are four keywords that need to be taken into account, namely scientific, rational, empirical, and systematic [4]. Mukhtar points out that the descriptive qualitative method seeks to describe all the symptoms or conditions that exist, namely the state of symptoms according to what they were at the time the research was conducted [5]. According to Spradley, describing ethnography refers to the work of describing a culture with the main objective of understanding the life view from the natives' perspective and its relations with life to gain a view on their world [6]. The findings obtained from the natives' perspective are the type of knowledge that is different from the knowledge of the outsiders, even if they are trained social scientists or experts. In essence, ethnography is an attempt to pay attention to the meaning of the actions of events that happen to people we want to understand.

The most important and inseparable part of ethnography, which also serves as the main technique of this research, is the incorporation of participatory observation. On the other hand, the study of ethnography is also an integral part of anthropology, which means that the participatory observation and anthropology are one entity. According to Spradley, ethnography is a type of work which aims to explain a culture. The main objective of ethnography is to understand how other people live from their own perspective. Understanding culture by learning from the people or community where the culture comes from or belong to is indeed one of the stages in an ethnographic research process.

Nevertheless, participatory observation is not the only method used in this study as it involves a field strategy which simultaneously integrate document analysis, indepth interviews, and other techniques.

In-depth interview, life history, document study, etc. are often associated with participatory observation because they ensure the validity of the data by explaining the verbal data as well as the spontaneity of behaviour in the natural habitat or environment.

Ethnographic research is structured slightly differently from other social studies. The first step is to select an ethnographic project, in which the researcher must consider the investigation that will be carried out on the informants. Ethnographic fieldwork begins when researchers successfully answer ethnographic questions that have been prepared beforehand. Ethnographic questions are structured as the means of collecting ethnographic data. Ethnographic data collection must consider the techniques employed based on participatory observation. During the data collection process, the researcher must record all interviews and all matters relating to ethnographic questions. Afterwards, the results of the observation are described in a macro approach, followed by a focused analysis on the issues that will be reviewed and reselected for a more micro coverage. The final result is to write an ethnographic report or work. It is recommended to write the report in detail immediately to recall some of the things that may not be properly recorded during the interview or data collection in the field. 


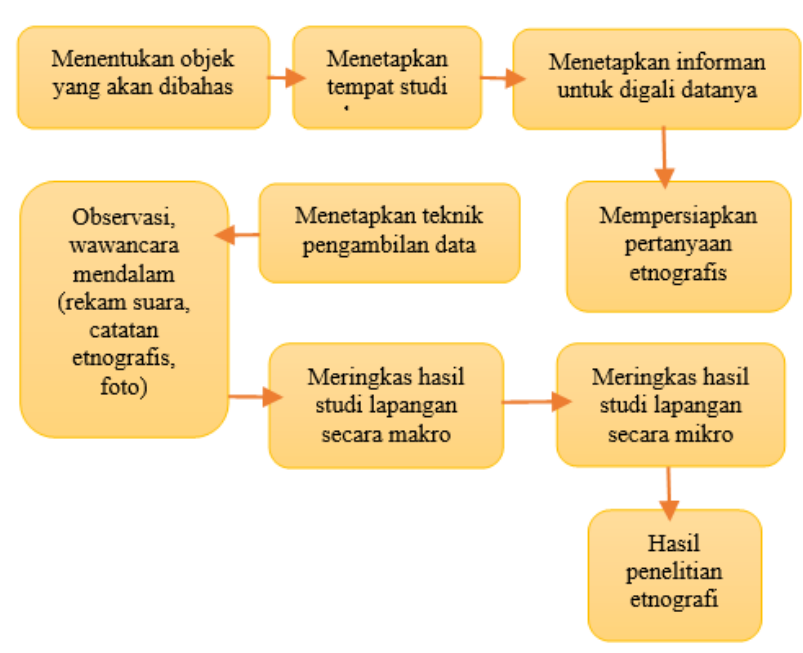

Scheme 1 Stages in an Ethnographic Research

Selecting the object to study $\rightarrow$ Selecting the research location $\rightarrow$ Selecting the informants to obtain data $\rightarrow$ Preparing ethnographic questions $\rightarrow$ Selecting the data collection technique $\rightarrow$ Observation, in-depth interview (voice recording, ethnographic note, photo taking) $\rightarrow$ Making a summary of the field study (macro) $\rightarrow$ Making a summary of the field study (micro) $\rightarrow$ Result of ethnographic research

\section{RESEARCH FINDINGS}

\subsection{Subandi Giyanto's Profile and Artistry}

Based on the interview conducted with Subandi Giyanto as the main research subject and informant of this study, it is found that the artist was born in Bantul in 22 June 1958. The son of Ngatiman (nickname) and Pirah, he graduated from elementary school in 1971, junior high school in 1974, and high school in 1979 from The Indonesian School of Fine Arts. He also studied at the Faculty of Teacher Training of Literature and Arts at the Yogyakarta State Institute of Teacher Training and Education. Following that, he opened a small painting studio in his house.

Subandi Giyanto is a retired civil servant that is now committed to pursue his artistic explorations. He has been involved in art since the age of 7 , when he was still in the first grade of elementary school. He learned the art of tatah sungging and making shadow puppets from his father, Giyanto Wiguna. In Grade 4, Subandi was instructed by his teacher, Mr. Pardjijo, to take part in exhibitions and handicraft competitions during the National Sports and Arts Week in which he won first place from the regional, provincial, to the national level from1969, 1970 to 1971.

Since then Subandi has always been invited to exhibitions in commemoration of national holidays every year. In 1972, Subandi was invited back by the elementary school to take part in the competition and regained first place again. In 1972-1974, in addition to participating in the competition, he also continued to make and perform shadow puppets. In 1975, Subandi was admitted to SSRI (the Indonesian Fine Arts School), where he realized that there are other forms of art besides the shadow puppet play.

In April 1975, SSRI held an art exhibition to commemorate its anniversary at the Senisono Gallery, south of the Yogyakarta's Gedung Agung. Subandi participated in the exhibition and realized that he could make art with the same quality as his colleagues. He also received the Pratita Adi Karya award for leather craftsmanship on shadow puppet. Following that, Subandi began trying another medium for his art, namely canvas painting.

In the next year, Subandi got involved in glass painting using social themes and wisdom messages as there was a great demand from the public at the time. One of them was the renowned artist Butet Kertaradjasa, who asked him for an idea of a sketch with his signature theme of social criticism or commentary.

Subandi also taught glass painting to a colleague's younger brother and taught at SMP 1 Yogyakarta as an honorary teacher in 1979. In 1980, while studying in the university, he taught at the Centre for Skills Development of Yogyakarta State University, as well as senior high schools such as SMA 9 Yogyakarta, SMA 10 Yogyakarta, and SMA 1 Yogyakarta. In 1980-1984, Subandi did a community service as a part of his tertiary education, and graduated from college in 1986. Then, he was appointed as a civil servant in 1996 and continued to work, exhibit and take part in competitions every year until now. As a senior artist, he is a respected figure in the glass painting community, especially those in his years. Needless to say, Subandi has an abundance of experience in the field of art.

By now, Subandi has produced hundreds of works as a glass painter. He now lives with his wife, Tukirah, and two children named Prasetia Pradana and Sintaningsih Utami in the Gendeng sub-village RT 05/ RW 02 No. 178 of the Bangunjiwo Village in the Kasihan District, Bantul Regency, Yogyakarta Special Region Province.

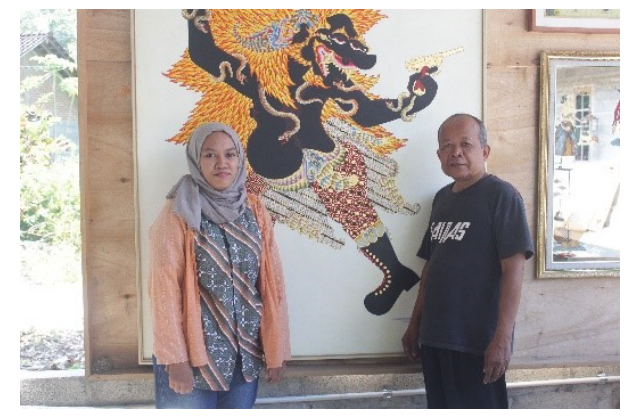

Figure 1 the Researcher and Subandi Giyanto 


\subsection{Transmedia of Shadow Puppet in the Works of Subandi Giyanto}

In this research, four samples of Subandi's works based on different mediums with the same shadow puppet theme are taken into account to represent the transmedia of his works. In regard to Subandi's journey as an artist, the works are put in a chronological order to compare Subandi's older works with his newer ones which contain modern elements.

As Subandi Giyanto began his career by making Yogyakarta-style shadow puppets, it is no wonder that the shadow puppet theme is identical with his works. For Subandi, the art of tatah sungging has opened the door to become an artist that he is today. The sunggingan style of Subandi's works are no different from the common sunggingan which uses colour block and gradation. Simple or soft colours of the classic shadow puppet colours such as red, green, yellow, blue, orange, purple, and white as the mixing colour are used with the varied types of paint, including acrylic, as well as wall paint for the sungging or block on the shadow puppet.

For the outline, Subandi uses the type F drawing pen. He has explored other mediums for producing shadow puppets such as the Malaga paper which he shapes as the shadow puppet making process in general, as well as the regular cattle leather (cow, buffalo, goat), and metal pieces cut by laser with the shadow puppet shape and design.

Subandi's works that incorporate modern elements are the two-dimension and three-dimension mediums. In the two-dimension medium, Subandi once tries collages with the leather that is cut into smaller pieces that he put back together and paint shadow puppet on the medium. Furthermore, he also produces his famous glass paintings with light humorous messages, and makes a painting filled with shadow puppet decorations in every inch of the space on the regular canvas without removing the main focus on the character in the painting. Some of them are added with a gold-leaf powder to provide a luxurious impression on the paintings. Subandi's latest three-dimension work is in the shape of a calf with decorative shadow puppet illustrations which is shown at his second solo exhibition entitled "Nunggak Semi" in Bentara Budaya Yogyakarta.

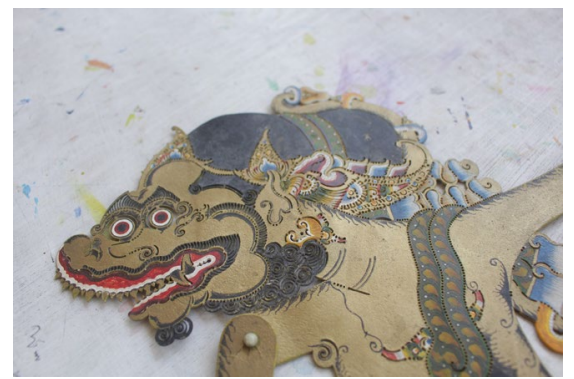

Figure 2 the Shadow Puppet of Subandi Giyanto
The shadow puppet was the first art form that Subandi worked on since he was seven years old and attended Elementary School. The shadow puppet was introduced by his father and his uncles who were shadow puppet craftsmen in Yogyakarta. Shadow puppet has been firmly embedded in Subandi since he was a child until he continues to be involved in the world of shadow puppets by regularly taking part in exhibitions and contests. Instead of a regular senior high school, Subandi attended the SSRI (the Indonesian School of Fine Arts) for his formal education, where he learned that shadow puppet was not the only form of art he could pursue as there were others he could explore. He tried the canvas and glass medium after being inspired by the giant painting of Yogyakarta State University students at the time. Subandi ultimately participated in the SSRI anniversary exhibition in 1975, and felt that he was finally equal among his peers which produced the best art pieces.

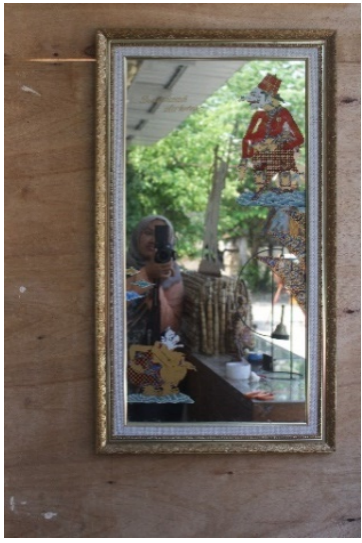

Figure 3 Painting on a Mirror

Subandi first tried glass painting when he was in Grade 11 in high school. His objects of painting include the purwo-stryle shadow puppet of Yogyakarta, the beber style of Wonosari, and the beber style of Pacitan with Javanese proverbs as the hidden message in his works. During that time, Subandi had also been playing with other media such as canvas, paper, and making collages from cut up pieces of leather.

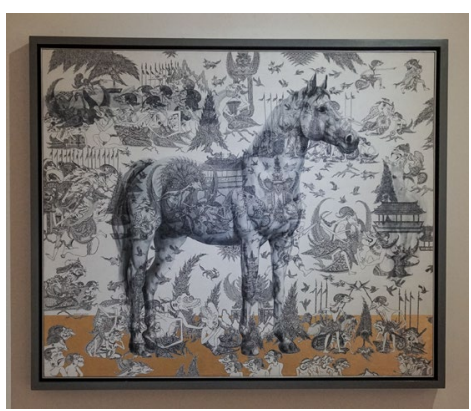

Figure 4 Canvas Painting entitled Diamku, Kudaku (My Silence, My Horse) 
In college, along with his experience in the art world, Subandi increasingly dared trying out various mediums to make art. His connections were getting wider and he never missed any competition and exhibition. Together with glass painting Subandi also tried the canvas media with the characteristics of the main object as a highlight or point of interest which was always painted prominently and dominated the space of the canvas. The main object was the background with shadow puppet decorations which were spread and filled the entire space of the canvas in a balanced composition, making it interesting to look at. The gold leaf powder addition also made Subandi's works more special. Whether as the main object or a decorative element, shadow puppet always has a special place in each of Subandi's work until today.

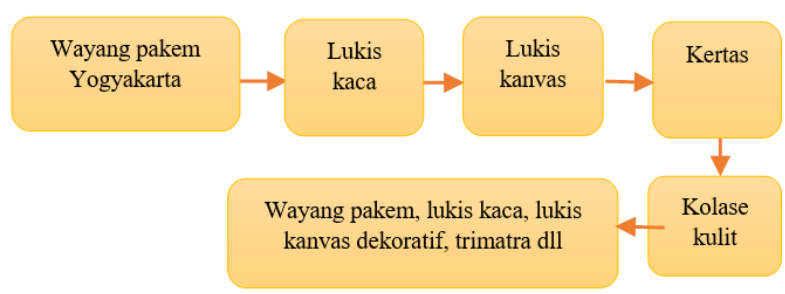

Scheme 2 the Metaphors in Subandi Giyanto's Works

Yogyakarta-style shadow puppet $\rightarrow$ Glass painting $\rightarrow$ Canvas painting $\rightarrow$ Paper $\rightarrow$ Leather collage $\rightarrow$ Shadow puppet, glass painting, decorative canvas painting, trimarta, etc.

As clearly described in the above scheme, in his career, Subandi evolves from the Yogyakarta-style shadow puppet to using trimarta as the medium. His works are getting bolder along with the more experience that he gets. In search for the identity in his works, Subandi kept attempting to try in his process to find a signature in each of his work. Finally, he found that the sunggingan techniques in the colouring process and the shadow puppet character are two elements that are always present in his works. There is no doubt that the shadow puppet has a big influence on Subandi's works. Until today, Subandi is consistently working with various mediums and open for suggestions to make his works better from his colleagues.

Subandi held his second solo exhibition titled "Nunggak Semi" at Bentara Budaya Yogyakarta in May 2019 with 29 pieces of canvas paintings, 12 glass paintings and 3 trimatra-installations. Subandi's first solo exhibition was held on May 29-June 13, 2004 at the Yogyakarta Pitoe Gallery. Subandi's entire work explores traditions to provide ideas of creating his works with the world of shadow puppet as the main narrative. In addition, he also did explorations in the development of the shadow puppet story, shadow puppet as a medium of social criticism, and the experiment of relating shadow puppet stories in today's context.
Subandi conveyed his social criticism and messages through glass painting with the Javanese titles such as Asu gedhe menang kerahe, Aja rebutan kursi, wong miskin dilarang sakit, Melik nggendhong lali, Yen bareng aja jegali, Yen ning buri aja nggendholi, Aja luntur ing panggoda, Sing duga lan prayoga, Aja watak wani wiring, Aja cedhak kebo gupak, and Becik ketitik ala ketara. Meanwhile, his canvas paintings are titled as follows Jangan Korupsi Mari Membangun Negeri, Hentikan Kerakusanmu, Jangan Rakus. Subandi's installation entitled Aja Adigang, Adigung, Adiguna not only employed shadow puppet, but also the animal and human figures. Finally, Subandi's trimarta piece is entitled Wuku Julungpujud on the body of a calf.

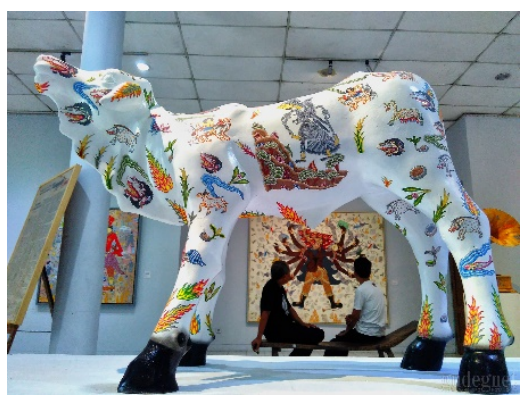

Figure 5 Trimatra Piece entitled Wuku Julungpujud

In the ethnographic concept that has been described, the concept embraced by ethnography can be used to examine transmedia or the development of Subandi Giyanto's work in the art world. In ethnographic research, informants must be present as the key to obtain important information that can support the validity of data before further processing. Based on the results of identification, Subandi Giyanto was the only informant who was interviewed in depth to obtain the actual data, as he was the creator of the well-respected works examined in the research which focused on the transmedia on the journey of his works from the beginning to the present. The indepth study conducted on Subandi Giyanto involved a field study consisting of an interview with ethnographic questions. The obtained data were the interview recordings and notes on Subandi's perspective as the creator of the artist. Moreover, the researcher also used academic papers on Subandi's works as the reference through an internet search. As a part of the participatory observation, the researcher also attempted to make one of Subandi's works, namely the Yogyakarta-style tatah sungging shadow puppet. 


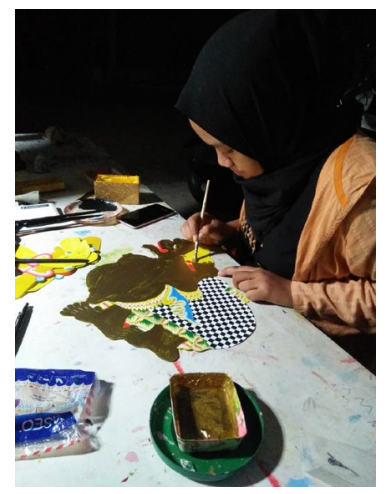

Figure 6 The researcher attempts to make a shadow puppet

\subsection{Local Wisdom in Subandi Giyanto's Works in the 4.0 Industrial Era}

In the development of the 4.0 industrial revolution, many issues are emerging, e.g. regarding the Gen- $Z$ teenagers. Tapscott defines Generation $\mathrm{Z}$ as those who were born between 1998-2008. This generation is also often referred to as the internet generation (igeneration) as most of their activities are related or associated with the virtual world or the internet. Since the time they are born, they have been familiar with technological advances and sophisticated gadgets [7]. Gadget is a product of the 4.0 industrial revolution which serves as the tool of preservation of traditional culture, including shadow puppet among teenagers.

According to Satya, Industrial Revolution 4.0 is a digitally connected industrial process that includes various types of technology, ranging from $3 \mathrm{D}$ printing to robotics which is believed to be able to increase productivity [8]. Therefore, it is necessary to hybridize culture with digital media because it is in accordance with the characteristics of the younger generation who are familiar with gadgets and who need speed in finding accurate information.

Subandi Giyanto is one of the many artists who work by utilizing the internet and gadgets to promote his work, even though he is no longer young. Subandi posts photos of his work on his personal Instagram account. The themes of Subandi's works are the hot issues discussed by the public. This allows the public to not only learn more about Subandi's works, but also Subandi Giyanto as the artist. Based on the interview, Subandi feels satisfaction every time his work is discussed online, whether in the form of an academic paper, or a simple photograph. He argues that this means that his works receive validations and have more track record not only in the form of art, but also academic papers on the art works.

\section{CONCLUSION}

With classical elements in his shadow puppet-themed works, Subandi Giyanto manages to maintain his existence as one of the most important artists in the current era of technology-oriented world.

As the first form of art he ever learned, shadow puppet has an important place in Subandi's works. He has become one with shadow puppet, as reflected in his works. It would not be Subandi's works without some elements of shadow puppet.

Subandi's background fully contributes to his career in the arts, as well as his involvement in teaching art. Today, Subandi Giyanto has retired and been busy with his projects in the village of Gendeng, Bangunjiwo, Kasihan, Bantul, Yogyakarta.

The transmedia journey of Subandi's works in fact addresses the current trend among the art world in order to increase interests on his art works. He does not only produce art in the actual sense, but also in the virtual form. Keeping up with the 4.0 industrial era, Subandi regularly uploads the photos of his latest works online in his personal Instagram account with a description of the works, as well as manages to convey his works through university students who write and conduct a research about his works. Such exposure allows Subandi to be well-recognized in the internet. In addition to that, it must be noted that his works stay true to his sunggingan style and shadow puppet as the major theme in his works.

Ultimately, Subandi's transmedia works also provide a history of exploration in each of his work. For example, the glass painting he did during high school or the canvas media he used in college. 


\section{REFERENCES}

[1] Kresna, Ardian, and Elis Widayanti. Dunia Semar [Semar's World]. Diva Press, 2012. p. 17.

[2] Susanto, Mikke. Diksi rupa: kumpulan istilah seni rupa [Fine diction: a collection of visual arts terms]. Kanisius, 2002. p. 385.

[3] Marsudi. Produk Kulit Tatah Sungging I [Leather Products Tatah Sungging I]. Jakarta: Kementerian Pendidikan dan Kebudayaan, 2013. p. 6.

[4] Sugiyono, Prof. Metodologi penelitian kuantitatif kualitatif dan $R \& D$ [Quantitative qualitative research and $R \& D$ methodology]. Alpabeta, Bandung, 2011.p. 3.

[5] Mukhtar. Metode Praktis Penelitian Deskriptif Kualitatif [Practical Methods of Qualitative Descriptive Research]. Jakarta: GP Press Group, 2013. p. 11.

[6] Spradley, James P., Misbah Zulfa Elizabeth, and Amirudin. Metode etnografi [Ethnographic method]. Tiara Wacana Yogya, 1997. p. 3.

[7] Don, Tapscott. Grown Up Digital: How the Net Generation is Changing your World. New York: McGraw Hill, 2009. p. 16.

[8] Satya, Venti Eka. "Strategi Indonesia Menghadapi Industri 4.0 [Indonesia's Strategy in Facing Industry 4.0]." INFO Singkat 10.9 (2018). p. 20. URL:

http://sdip.dpr.go.id/search/detail/category/Info $\% 2$ 0Singkat/id/816 